\title{
Challenging and Rare DNA Profiling of Burned Corpses at the State Forensic Science Laboratory of Jharkhand
}

Nand J K*, Soren AN and Singh $\mathbf{R}$

Division of DNA Biology Section, State Forensic Science Laboratory Jharkhand, India

*Corresponding author: Jwala Kumar Nand, State Forensic Science Laboratory, Ministry of Home Affairs, Near Birsa Munda Jail, Hotwar, Ranchi, Jharkhand 835217, India

Received: January 03, 2017; Accepted: February 20, 2017; Published: February 21, 2017

\begin{abstract}
Burning of corpses, most common in, the criminals and heinous crime cases and for the destruction of evidence more corpses are burnt in cremation often for destruction of evidence to obscure the crime scene and buried in boxed or dumped in the river or the graveyard. It's very cost effective reason to hide crime In the process of cremation temperatures about to $870-980^{\circ} \mathrm{C}\left(1,600-1,800^{\circ} \mathrm{F}\right)$ for $60-80$ min or longer, after burning the dead body only leaving severely burnt teeth and some remains of long charred bones. In various criminal and civil cases, there is a requirement of DNA profiling for ascertained identity of the person and also help to solve the paternity-related issues. In the present study, we present autosomal DNA profiling of 12 corpses as the sample (legally known as exhibits) from the crime scene, one of the very sensational cases of state Jharkhand of India. The DNA profiling test performs in state forensic science laboratory Jharkhand. DNA extraction from charred bones, the human nuclear DNA was tested by highly sensitive multiplex PCR and quantified via real-time PCR; gene typing was done using the AmpFISTR Identifier Plus ${ }^{\circledR}$ kit.
\end{abstract}

Keywords: Cremation; Charred bones; AmpFISTR identifier plus ${ }^{\circledR}$; Nuclear DNA

\section{Introduction}

Typing of short tandem repeats (STR, "DNA profiling") is advanced tools When analyzing DNA extracted from human bones or teeth (modern or ancient), traces very minute amounts of DNA less than 1ng or highly degraded charged spongy tissues can use for identification purposes [1-3]. In forensic science laboratory DNA profiling is routine work, usually to confirm identity or post-obituary paternity testing. In cases of burial, the body can easily exhume for examination and scientific investigation. Due to the development of genetic analysis, e.g. Sequencing of nuclear short tandem repeats, biological material (i.e. Biopsies, blood samples, bones, hairs, teeth, saliva etc) taken for medicolegal examination can successfully be analyzed even after long time storage or properly preserved, while STR typing after cremation is of questionable value. Commercially available and globally accepted multiplex PCR AmpFISTR Identifiler Plus" kit which amplify up to 15 loci plus one gender locus Amelogenin gene in one reaction mixture and for highly degraded sample AmpFISTR Minifiler kit which amplify up to 9 loci plus one gender locus Amelogenin [4-5].

\section{PCR inhibitors}

There are many PCR inhibitors that target the DNA polymerase directly or indirectly. Proteases or detergents present in the reaction can degrade this enzyme. For example, urea and phenol are known to degrade DNA polymerases. Calcium, collagen, hematin and tannic acid may inhibit polymerase activity, melanin forms a reversible complex with the DNA polymerase. Humic acids interact with the template DNA and the polymerase thus preventing the enzymatic reaction, even at low concentrations. High concentrations of calcium may lead to a competitive binding by the DNA polymerase instead of magnesium and complexing agents, magnesium is no longer available as a cofactor for the polymerase and its activity is decreased [6]. The samples resulting with complete inhibition treated with new dual cycle EtO-treated Microcon DNA Fast Flow PCR-grade devices catalog No. MRCFOR100ET use for efficient concentration, desalting, or buffer exchange of aqueous biological samples. Our aim of this work was to systematically investigate whether human remains after cremation can be reliable for the establishment of individuality.

\section{Case history}

At the police station an FIR launch by police personhood under sections: 302/201/120(B)/34 of Indian Penal Code on the basis of secret information that a female, namely ABC Kumari (identity has been concealed), age 16 years killed brutally by their own family members and for destruction evidence they burned their dead body completely, after that all family members abscond. The investigation agency collected 17 blackish gray small charred bone pieces along with some ashes. It was received at state forensic science laboratory Jharkhand. From that so-called identity of person ascertain.

\section{Materials and Methods}

\section{Sample}

After cremation, the remains were collected by authority, 17 exhibits generally blackish gray small bones and some gray long bone as they were burned and charred it need screening and preprocessing.

\section{Sample preparation}

The surface of the skeletal element was removed using a sand paper in order to eliminate potential contamination and burnt tissue adhered to it, Samples were then cut into thin slices and washed twice with $5 \%$ sodium hypochlorite for $15 \mathrm{~min}$, then rinsed properly and soaked in water for $15 \mathrm{~min}$, once rinsed in $70 \%$ ethanol and finally 
Table 1: Mean DNA concentrations for each bone sample for both extraction Ct values noted as ">40" correspond to "undetected" values. Software: 7500 SDS V.1.2.3

\begin{tabular}{|c|c|c|c|c|}
\hline SI. No. & Sample No. & Approx. Yield (ng/ $\mu \mathrm{l})$ & Mean cat IPC & Mean Ct Sample \\
\hline 1 & Exhibit marked-1 (Source: Charred bones) & 0.0003 & 27.99 & 30.61 \\
\hline 2 & Exhibit marked-2 (Source: Charred bones) & 0.001 & 27 & 32.96 \\
\hline 3 & Exhibit marked-3 (Source: Charred bones) & 0.002 .5 & 28.85 & 33.31 \\
\hline 4 & Exhibit marked-4 (Source: Charred bones) & Undetected & 37.96 & Undetected \\
\hline 5 & Exhibit marked-5 (Source: Charred bones) & Undetected & 38 & Undetected \\
\hline 6 & Exhibit marked-6 (Source: Charred bones) & 0.0005 & 27.5 & 32 \\
\hline 7 & Exhibit marked-7 (Source: Charred bones) & 0.182 & 27.99 & 30.61 \\
\hline 8 & Exhibit marked-8 (Source: Charred bones) & Undetected & 36.59 & Undetected \\
\hline 9 & Exhibit marked-9 (Source: Charred bones) & 0.0017 & 26 & 30.96 \\
\hline 10 & Exhibit marked-10 (Source: Charred bones & 0.0852 & 28 & 29.96 \\
\hline 11 & Exhibit marked-10 (Source: Charred bones) & 0.0015 & 27.96 & 30.85 \\
\hline 12 & Exhibit marked-10 (Source: Charred bones) & Undetected & 35 & Undetected \\
\hline
\end{tabular}

Table 2: Autosomal STR DNA profile Comparative Chart of allele distribution (genotype) of 15 different loci of the DNA tested.

\begin{tabular}{|c|c|c|c|c|}
\hline SI. No. & Name of loci & $\begin{array}{l}\text { Exhibit marked- A (Source: Charred } \\
\text { bone piece no. } 7 \text { ) }\end{array}$ & $\begin{array}{l}\text { Exhibit marked-A (Source: Charred } \\
\text { bone piece no. 10) }\end{array}$ & $\begin{array}{c}\text { Exhibit marked B (source: blood } \\
\text { sample of father) }\end{array}$ \\
\hline 1. & D8S1179 & 10,10 & 10,10 & 11,10 \\
\hline 2. & D21S11 & 29,30 & 29,30 & $30,30.2$ \\
\hline 3. & D7S820 & 7,10 & 7,10 & 11,10 \\
\hline 4. & CSF1PO & 13,13 & 13,13 & 13,13 \\
\hline 5. & D3S1358 & 15,15 & 15,15 & 15,21 \\
\hline 6. & THO1 & 6,10 & 6,10 & 6,10 \\
\hline 7. & D13S317 & 8,12 & 8,12 & 8,11 \\
\hline 8. & D16S539 & 9,9 & 9,9 & 9,10 \\
\hline 9. & D2S1338 & 18,19 & 18,19 & 15,19 \\
\hline 10. & D19S433 & 13,14 & 13,14 & 14,14 \\
\hline 12. & TPOX & 9,13 & 9,13 & 13,14 \\
\hline 13. & D18S51 & 13,18 & 13,18 & 12,18 \\
\hline 14. & D5S818 & 10,12 & 10,12 & 14,12 \\
\hline 15. & FGA & 20,21 & 20,21 & 20,19 \\
\hline 16. & Amelogenin & $X, X$ & $X, X$ & $X, Y$ \\
\hline
\end{tabular}

rinsed in $100 \%$ ethanol. The samples were left to dry overnight at room temperature.

\section{DNA extraction}

From each, the respective bone piece makes a powder using liquid nitrogen one gram of bone powder was incubated in $10 \mathrm{ml}$ of $0.5 \mathrm{M}$ EDTA, $\mathrm{pH} 8.5$ solution for $24 \mathrm{~h}$ at room temperature continuous rotation of the rotor at speed $40 \mathrm{RPM}$. The next day the list centrifuge at 3000 RPM for supernatant was discarded, and the EDTA solution was changed two more times. After 3- 4 days of decalcification each bone paste. We're submerged in $400 \mu$ of extraction buffer $(10 \mathrm{~mm}$ Tris-Cl, pH 8.0, 0.1M EDTA, pH 8.0, $20 \mu \mathrm{g} / \mathrm{ml}$ RNase A, 0.5\% SDS) in separate $15 \mathrm{ml}$ capacity falcon tubes for 1 hours at $37^{\circ} \mathrm{C}$. Proteinase $\mathrm{K}$ (Mark GeNitm) $(4 \mathrm{mg} / \mu \mathrm{l})$ was then added and incubated for further 12-15 hours at $56{ }^{\circ} \mathrm{C}$ with periodic swirling 120 RPM. The solution was brought to room temperature and subjected to Organic methods of DNA extraction. The tubes were stored at $4{ }^{\circ} \mathrm{C}$ until its use.

\section{DNA quantification}

DNA quantification of the 12 samples (Table 1) was performed by real-time polymerase chain reaction (RT-PCR) using the Quantifiler Human DNA Quantification kit (Life Technologies Inc.) [7] Containing DNA standard solution (200ng/ $\mu$ l), Quantifier Human Primer mix, and Quantifier PCR Reaction Mix. Human Primer Mix $(10.5 \mu \mathrm{l} /$ sample) and PCR Reaction Mix $(12.5 \mu \mathrm{l} / \mathrm{sample})$ were mixed and then dispensed into reaction wells $(23 \mu \mathrm{l}$ each) followed by the addition of $2 \mu \mathrm{l}$ of sample or standard DNA of known concentration to each well, to obtain a $25 \mu \mathrm{l}$ PCR reaction system. The amount of DNA was calculated by the real-time PCR machine (Applied Biosystems) and Software: 7500 SDS V.1.2.3. 


\section{Identifier plus ${ }^{\circledR}$ PCR and electrophoresis}

AmpFISTR Identifiler Plus kit [8] was used to multiplex PCR reaction for co-amplification of 15 autosomal STRs loci and a gender locus (Table 2). Using $25 \mu \mathrm{l} \mathrm{PCR} \mathrm{amplification} \mathrm{mixture} \mathrm{(10.5} \mu \mathrm{l} \mathrm{of} \mathrm{PCR}$ reaction mix, $5.5 \mu$ l of Identifier Plus Primer Set, $9.0 \mu$ l of nucleasefree water and $1 \mu \mathrm{l}$ of DNA template), amplification was carried out under conditions of initial denaturation at $95^{\circ} \mathrm{C}$ for $10 \mathrm{~min}$, followed by 29 cycles of denaturation at $94^{\circ} \mathrm{C}$ for $1 \mathrm{~min}$, annealing at $59^{\circ} \mathrm{C}$ for $1 \mathrm{~min}$ and extension at $72^{\circ} \mathrm{C}$ for $1 \mathrm{~min}$, and a final extension step at $60{ }^{\circ} \mathrm{C}$ for $60 \mathrm{~min}$. The PCR products were then examined using a $10-\mu \mathrm{l}$ electrophoresis system containing $0.3 \mu \mathrm{l}$ of Gene Scan ${ }^{\prime \prime} 500$ LIZ Size Standard dye, $8.7 \mu \mathrm{l}$ of $\mathrm{Hi}-\mathrm{Di}^{\star}{ }^{\star}$ formamide and $1.0 \mu \mathrm{l}$ of PCR product or the AmpFISTR' Identifiler Plus allelic ladder. Capillary electrophoresis was performed on an ABI-3130 Genetic Analyzer using $36 \mathrm{~cm}$ 4-capillary array (Applied Biosystems). Sizing of the DNA fragments was carried out using Gene Mapper ID software v3.2 with respect to Gene Scan" 500 LIZ" Size Standard. The resultant allelic distribution (genotypes) obtained from the studied loci in the exhibits is shown in the Table 2.

\section{Results}

The DNA test performed on the exhibits noted above is sufficient to conclude that:

The DNA profile generated from the source of Exhibit marked-A (Source: Charred bones exhibit marked 7 and 10) Table 2; is from one and same human female source of origin and all the paternal and maternal alleles accounted to be present in the Exhibit marked-A (Source: Charred bones exhibit marked 7 and 10) at all sixteen loci. The amount of DNA yield exhibit marked 7 and 10 were 0.182 (ng/ $\mu \mathrm{l})$ and $0.0852(\mathrm{ng} / \mu \mathrm{l})$ respectively; Table 1.

No DNA profile generated from the remaining source of Charred bones exhibit as the amplifiable amount of DNA could not extract; Table 1. Ct values noted as " $>40$ " correspond to a relatively high degree of inhibitors. This study shows that even though the extraction and subsequent STR typing of DNA from the charred bones cremated person is possible and in some exhibits does yield reproducible.

\section{Discussion}

In this article successful DNA profile were generated from 2 burnt remains Rare and challenging exhibits as often obscure the crime scene and present a huge challenge such as degraded and charred bone, mainly the challenges with bone tissue as well as soils there is also PCR inhibitor which co-purify during the DNA extraction process. PCR inhibition was also observed for real-time PCR assays, the interference with the fluorescent probes or increased background fluorescence represents additional mechanisms of action for PCR inhibitors decreasing sensitivity. The results of quantification obtained by real-time PCR from 12 samples. The DNA samples which were mixed with inhibitor amplification done with dilution at ratio 1:50; however the DNA profile generated from the diluted product was partial and uninterpretable. The samples resulting in partial inhibition were treated with the new dual cycle EtO-Microcon DNA Fast Flow PCR-grade devices catalog No. MRCFOR100ET enable centrifugal concentration at a similar rate as the Microcon DNA Fast Flow devices, but the EtO treatment greatly reduces the risk that no uncontrolled contaminating nucleic acids enter the analysis process. Then $0.5 \mu$ from each of these samples was used for PCR amplification. The complete DNA profiles were generated and no any drop out of alleles or loci observed in the sample charred bones exhibit marked 7 and 10. However, proper surface cleaning of the remains to remove external contaminant or dirt must be ensured. Interpretation of STR data should be ensured for the authenticity of the results. Solving a forensic case valiant and scientifically is a reward in itself for the forensic experts and the police involved in the case.

\section{Conclusion}

This study shows that even though the extraction and subsequent STR typing of DNA from the charred bone are possible and in some cases does yield reproducible results, a reliable post-cremation identification seems to be unlikely. Since the profiles did also not match those of the lab personnel. STR typing of cremation remains has to be considered some sample remains after carefully selecting, screening and preprocessing suitable for forensic purposes (e.g. Identification, paternity testing). Further studies needed to for a more appropriate yield of DNA, removal of PCR inhibitors and high throughput sequencing required to know the level of degradation.

\section{References}

1. Hagelberg E, Gray IC, Jeffreys AJ. Identification of the skeletal remains of a murder victim by DNA analysis. Nature. 1991; 352: 427-429.

2. Jeffreys AJ, Allen MJ, Hagelberg E, Sonnenberg A. Identification of the skeletal remains of Josef Mengele by DNA analysis. Forensic Sci.Int. 1992; 56: 56-76.

3. Alonso A. Andelinovic S, Martin P. Sutlovic D, Erceg I, Huffine E, et al. DNA typing from skeletal remains: evaluation of multiplex and Megaplex STR systems on DNA isolated from bones and teeth samples. Croat. MED. J. 2001; 42: 260-266.

4. Thomson JA, Ayres KL, Pilate V, Barett MN, Walker JIH, Debenham PG. Analysis of disputed single-parent/child and sibling relationships using 16 STR loci. Int. J. Leg. MED. 2001; 115: 128-134.

5. Sambrook J, Fritsch Ef, Maniatis T. Molecular cloning: A laboratory manual. New York: Cold Spring Harbor Laboratory Press. 1989.

6. Sutlovic D, Definis Gojanovic M, Andelinovic S, Gugic D, Primorac D. Taq polymerase reverses inhibition of quantitative real time polymerase chain reaction by humic acid. Croat. Med. J. 2005; 46: 556-562.

7. Green RL, Roinestad IC, Boland C, Hennessy LK. Developmental validation of the quantifiler real-time PCR kits for the quantification of human nuclear DNA samples. J Forensic Sci. 2005; 50: 809-825.

8. Wang DY, Chang CW, Lagace RE, Calandro LM, Hennessy LK. Developmental validation of the AmpFISTR ${ }^{\circledR}$ Identifiler ${ }^{\circledR}$ Plus PCR Amplification Kit: an established multiplex assay with improved performance. J Forensic Sci. 2012; 57: 453-465.
Austin J Forensic Sci Criminol - Volume 4 Issue 1 - 2017 ISSN : 2380-0801 | www.austinpublishing group.com Nand et al. @ All rights are reserved
Citation: Nand JK, Soren AN and Singh R. Challenging and Rare DNA Profiling of Burned Corpses at the State Forensic Science Laboratory of Jharkhand. Austin J Forensic Sci Criminol. 2017; 4(1): 1056. 